\title{
Making Connections While Earning an MLIS
}

By: Sarah Loor and Michael A. Crumpton

Loor, S. \& Crumpton, M.A. (2016). Making Connections While Earning an MLIS. The Bottom Line, 29(3). http://dx.doi.org/10.1108/BL-05-2016-0022

***This version $\odot$ Emerald Group Publishing Limited. This is not the final version. This article has been accepted for publication in The Bottom Line, published by Emerald Group Publishing Limited. Reprinted with permission. Figures and/or pictures may be missing from this version of the document. The version of record is available at http://dx.doi.org/10.1108/BL-05-2016-0022.****

\author{
Abstract: \\ Purpose \\ This article discusses a collaboration with a non-profit organization conducted as part of the Real \\ Learning Connections project at the University of North Carolina at Greensboro. We discuss our \\ experiences working with a non-profit partner from outside the university and the benefits gained \\ from collaboration. \\ Design/methodology/approach \\ This is a reflection based on the personal experiences of the authors as collaborators in the \\ project.
}

Findings

Through our experience with the Real Learning Connections project, we found that collaborating with a non-profit organization provides a unique opportunity for library school students to learn practical skills while also providing value to the non-profit organization in the form of expertise in information services.

Originality/value

This piece discusses the benefits of collaboration from the perspective of both an LIS student and a professional librarian, as well as considering the experiences of an external non-profit organization.

Keywords: Real learning connections | collaboration

\section{Article:}

Schools of Library and Information Studies typically offer students the opportunity to apply theory learned in the classroom to practical learning experiences such as practicum assignments, internships, service learning, or independent study opportunities. Being able to learn practical skills while earning the graduate degree can prove very valuable (Coleman, 1989). The quality of such opportunities varies considerably as the profession debates the perceived value of practice versus theory (Ball, 2008). 
At the same time, libraries are working beyond their walls to provide information to connect to other non-profit organizations (Salinas \& Chabrán, 2005/2006). Libraries seek opportunities to develop these relationships and provide influence on a broader scale. In this article we describe the activities of combining an internship for a LIS graduate student with the outreach efforts of the university library. This experience not only enhanced the perceived value of the MLIS degree earned, but also provided the library an opportunity for a long term collaborative relationship with another non-profit.

\section{Introduction}

The term "experiential learning assignment" includes, but is not limited to, internships, practica, and service learning. Experiential learning opportunities may be paid or unpaid, academic or nonacademic, University-sponsored, or independent and may take place outside the University environment. Thus the Real Learning Connections model was created to explore an in depth opportunity for learning. At the interstices of the model are the areas of concern that will be affected by the interaction between the participants. Academic content is both what the practitioners learned in their own programs of study and the content of the curriculum (Bird \& Crumpton, 2014). Practical work experience is the nature of the tasks completed. Current theory and research are both the work of the faculty member involved and a connection to the literature.

For 7 years the University Libraries and the Department of Library and Information Studies at the University of North Carolina at Greensboro have collaborated on a learning partnership called Real Learning Connections. This is a unique venture that triangulates the work of a faculty member, a practitioner and a student, the goal being to harness the learning power that could be shared among these three in a collaborative way. Experiential learning opportunities for students in the Department of Library and Information Studies are work experiences that allow them to sample professional environments in which they might seek a career or which might give them experience to help prepare them for a career or enhance their current career.

The concept of this program has involved the convergence of theory and practice; using a LIS graduate student as a conduit, projects have been undertaken that create learning objectives for not only the student, but the librarian(s) and LIS faculty member(s) involved for each individual project. The administrators of the Real Learning Connections have published* and presented on the different projects completed and what was learned from all parties involved. Each year new variables are added to the projects' execution and the overall research goal is to create a sustainable internship model that fosters professional growth for students, organizational learning for practicing librarians and curriculum assessment and modification for the LIS department.

One of the more recent projects has been to provide outreach to a non-profit organization in the form of professional expertise with regard to resource allocation and accessibility. This project provided tangible support for a non-profit enterprise, sought to broaden research on the subject of domestic violence in order to help those affected, achieved learning objectives for a second year LIS student with a related background in the subject area and established collaborative teams with both the library and LIS department organizations for working beyond the walls of campus.

From this project the Real Learning Connections program is hoping to define a model for sharing expertise and learning opportunities at an organizational level with community groups or 
non-profits. This model can help produce foundational support, using professional library science expertise for other organizations across a variety of needs. This takes organizational commitment as projected needs could cross departmental lines and subject or discipline knowledge.

\section{Intern Background}

When Sarah first came on board to Real Learning Connections, she was excited about the opportunity to work on a project that would incorporate her pre-library school experience. Like many of her fellow students, she entered the MLIS program after spending some time in another field. In her case, she was an attorney who had worked in the non-profit immigrant advocacy field. One area that she specifically focused on during her internships and her clinical experience in law school was advocacy for immigrant survivors of domestic violence. There are immigration remedies that exist for people who have experienced domestic violence and other crimes. These remedies exist in order to encourage the reporting of such crimes, whose victims might otherwise be too afraid to advocate for themselves. As an intern and law clinic student, Sarah worked with people who had survived intimate partner violence, sexual assault, and human trafficking to help them move toward building a life free of abuse. She enjoyed many things about this work, but she was especially driven by the goal of working as part of a team to help people gain access to the resources they needed to reach their goals of a better life.

In many ways, deciding to pursue an MLIS degree at the University of North Carolina at Greensboro was a logical progression of the career path Sarah had started in law. She wanted to focus on helping connect people with the resources they needed to accomplish their goals. When she started the program, she saw the potential for the degree to be used to help effect positive social change, but wasn't sure where her specific path would lead. When the opportunity emerged to work with the National Resource Center on Domestic Violence (NRCDV) through the Real Learning Connections project, Sarah saw that the past experience she had worked to gain in the legal field was coming together with the things she had been learning during her library school courses to help create a unique learning experience.

\section{VAWnet}

The National Online Resource Center on Violence Against Women (VAWnet) is a project of the National Resource Center on Domestic Violence (NRCDV) and has a comprehensive and easily accessible online collection of full-text, searchable materials and resources on domestic violence, sexual violence and related issues. Sarah's main objective during the course of the school year spent working on the Real Learning Connections project was to learn more about digital scholarship. One of the courses she had taken the summer before beginning the Real Learning Connections project focused on this topic and this project was a chance to put what she had learned in the class into practice.

Much of Sarah's work on this project focused on finding new digital content to submit to the NRCDV for inclusion in VAWnet's database of resources. She was free to look for any resources as long as they were high-quality, open-access, and related in some way to the topic of violence against women. Some of the content she found was what would more traditionally be considered scholarly publication. Since one target audience for VAWnet is lawyers and legal support staff, Sarah's legal background was an asset that helped her find relevant law review 
articles. Law journals are often available to anyone on an open-access basis, with many hosted on the Digital Commons Network. Even for the many users of VAWnet who are not legal professionals, law review articles can be a valuable resource, as they often discuss cutting edge issues in-depth.

VAWnet's manager had also specified that new content from state and local level antiviolence organizations would be welcome additions to the site. Sarah also looked for content from national level organizations. Searching for this type of content was different than the type of research we typically do in academia. There was no centralized database to use to begin searching. Instead, Sarah had to rely on using her searching skills to find websites of relevant organizations and investigate what each organization offered in terms of resources. Finding one good resource would often lead to others. Some of the resources found fell into the realm of more traditional articles. Other resources included things like tipsheets, videos, and webinars. Working on this project reinforced the idea that in the digital age, many different people and organizations can be content creators and that much high-quality content is available for free.

During the project, Sarah also learned more about the technical aspects of digital scholarship. She shadowed VAWnet's manager to learn how she adds new content to the site and studied HTML via free lessons available online through Codecademy. She explored the idea of incorporating filtered searching into VAWnet's search structure so that users could narrow and broaden their searches as they went along without having to create multiple new searches. Searches would become more efficient and users would be better able to connect with the precise content they needed from the huge amount of content available on VAWnet. Finally, Sarah performed analysis of search terms people use in Google to find VAWnet in order to help the NRCDV determine whether any changes could be made to the proposed structure of their new website so that people could more easily find resources on frequently searched topics.

Sarah also learned more about the possibilities available for a website to utilize digital scholarship by researching potential next steps for VAWnet and presenting them to the VAWnet team. One potential way for a website like VAWnet to efficiently provide access to a broad variety of content would be linking to institutional repositories. The site could create a page with a listing of scholars who write about issues relevant to that site's topic, a brief description of each scholar's general research topics, and a link to each scholar's page at her university's institutional repository. While work deposited in institutional repositories may be an author's personal copy of the text and may not have the formatting that is applied to the published version in a journal, linking to such work would allow a site like VAWnet to provide free access to content that might otherwise be found only as a paid resource.

Another option we explored was the idea of a site like VAWnet linking to statewide library websites, which allow residents of specific states to access resources such as article databases and ebooks. For example, the statewide library site in North Carolina is called NC LIVE. Access is available via credentials provided by public libraries throughout the state, and people who have an affiliation with a North Carolina community college, college, or university can access NC LIVE using credentials from their institution as well. A site like VAWnet could consider having state-specific resource pages. A user could select her own state and be taken to a page that would link to that state's online library. Other statespecific resources could be provided here as well. In the case of VAWnet, resources could include a link to that state's domestic violence coalition, links to other organizations within that state that produce resource materials on violence against women, and links to state statutes on domestic violence. 


\section{Organizational Gains}

As stated earlier, part of the objectives for Real Learning Connection projects is to provide multiple learning opportunities for those involved. This project scope was intended to provide expertise for VAWnet as it relates to the organization and classification of the information they were making available for researchers. This starts by identifying resources that are freely available, such as institutional repositories, but that must be sought out and discovered in order to be added or linked into VAWnet's purview. Subsequent options become available as mentioned, such as state consortium sites or targeted subscription services for subject specific needs.

VAWnet's gain in this project was to become informed on information seeking and retrieval techniques such as search schemas, tagging of keywords or concepts, and metadata techniques for content optimization. Part of this project's outcome was to make the case advocating the need for librarian expertise and training within VAWnet's organizational structure.

The role of the University Libraries and the Department of Library and Information Studies at UNC at Greensboro was to operationalize the concept of non-profit collaboration by sharing expertise, in this case through Sarah as a graduate student. For the libraries, this project enables librarians to become embedded in an organizational service arena with another nonprofit. The library school could evaluate how working across environments could impact Howard Gardner's theory of multiple intelligences to improve the curriculum, as described by Cargo (2000). Cargo concluded that libraries can provide the means by which other disciplines can develop multiple access points of understanding and knowledge.

The faculty member involved in this project already had connections with VAWnet and was able to help coordinate the roles of the intern and the libraries in order to produce a tangible outcome for both. In addition, the Department of Library and Information Studies was able to gain a new experience that could be shared with other faculty members to broaden this type of project or approach when working with students on their practicums and internships. This further can influence the curriculum by providing curriculum development strategies beyond collective faculties' expertise (Bird \& Crumpton, 2014).

\section{Our Journey on Learning}

The Real Learning Connections program also gave Sarah the experience of working to help a real-world organization with its information needs. While she had been assigned other projects as part of her coursework that attempted to simulate real-world projects as much as possible, there is really no substitute for actual first-hand experience. The project showed the need for flexibility when goals change during the course of project and the importance of following the client's lead. In an article about a partnership between a health sciences library and a community organization dedicated to services for parents of children with autism, Alfasso (2011) discusses some of the logistical challenges that can arise during the course of a partnership. Alfasso writes about how waiting for a county library budget to be passed affected the ability to schedule meeting rooms for the partnership project (p. 71). Similarly, we faced some delays in getting started while VAWnet was waiting for a contract to be finalized. Since the project only ran for one academic year, this delay did affect the amount of services we were able to provide, but we worked to find other things we could help with in the meantime that 
didn't require contract finalization, such as Sarah locating new content for VAWnet. Alfasso also discusses how "scheduling meeting times when all parties could be present" was a challenge for the partnership with the autism organization (p. 71). Scheduling could also be a challenge during the Real Learning Connections project, since we had so many collaborators and since we were geographically distant (the UNC at Greensboro collaborators were in North Carolina and the VAWnet collaborators in Pennsylvania). We were able to use technology tools such as WebEx, Blackboard Collaborate, and JIRA project tracking software to help us bridge the distance.

Salinas and Chabrán (2005/2006), reflecting on past library partnerships for increasing access to technology for Latino communities, write, "We were mindful that we were often perceived as agents of a large university. Part of the partnership development was articulating a clear understanding of what our goals were, what we could do, and what we could not do" (p. 133). At times we similarly needed to convey that certain library resources (for example, access to electronic resources licensed by the university) could not be included within the scope of the project, while always making sure to communicate what the services were that we could offer.

We would highly recommend that other LIS students seek out similar collaborative experiences to help put the skills they are learning in their programs into practice and to help information seekers achieve their goals. Collaborations like this one between library schools and non-profit organizations are mutually beneficial to both parties. Students gain valuable experience and non-profits, which often run on tight budgets, gain access to librarian and library student expertise in information organization.

Collaborations also offer students a chance to make a more personal connection with librarians, LIS faculty, and non-profit professionals. Since Sarah completed her degree as a distance education student, this was especially important in her case. Michael served as a mentor during the course of this project to guide Sarah in the development of these new skills. At times when work on the main project with VAWnet was a bit slower on our end while waiting for direction from the NRCDV, he was able to direct her to related projects to keep building her experience with digital scholarship. For example, she had the opportunity to edit articles for the Journal of Learning Spaces, an open-access digital journal hosted by the university, which helped her see how the production of digital scholarship happens behind the scenes.

The experience of working with VAWnet and the Real Learning Connections project has helped Sarah immensely with the transition to professional employment after graduation. She will be working with a legal organization to help organize online information, so the VAWnet project was instrumental in helping her to be prepared for the job. When she first started library school, she had solid experience in the legal world but needed the formal education provided by the MLIS program to help transition to putting that experience to work in the information services field. The project helped Sarah envision the ways that the skills gained in an MLIS program could be leveraged in ways other than traditional work in a library and gave her the confidence to pursue a nontraditional position. While all of the coursework in the program was valuable, she considers the Real Learning Connections project to be the key that has truly prepared her the most for work as an information professional.

Working on a project that extended beyond the bounds of the library also allowed us to fulfill goals of both the LIS department and the university library. The UNC at Greensboro LIS program's mission is to "connect people, libraries, and information through research, teaching and service to enrich living and working in a global environment" (The University of North Carolina at Greensboro School of Education, 2013). Through the Real Learning Connections project, we forged connections among our department, our university library, and a non-profit 
organization in order to provide enhanced service to the diverse community of users that relies on VAWnet for information. The UNC at Greensboro University Libraries mission statement reminds us that "through expertise in information services, the University Libraries foster the success and impact of the UNC Greensboro community by promoting learning, inspiring creativity and enhancing research and collaboration in a diverse and innovative environment" (The University of North Carolina at Greensboro Walter Clinton Jackson Library, 2015). This project allowed those of us at the university to collaborate successfully with a nontraditional partner in a way that can serve as a model for future collaboration between libraries and community organizations.

Describing their partnership experience, Salinas and Chabrán (2005/2006) write, "Working beyond the library walls has been both a privilege and an honor. The experience transformed us in many ways. We have come to appreciate that good partnerships are not born but nurtured" (p. 134). Our experience working with VAWnet has similarly taught us how to work in partnership with a community organization and we hope that future partnerships with other organizations will continue to thrive at our institution and others

\section{References}

Alfasso, A. (2011). Information literacy instruction for community members: An academic partnership with a community nonprofit organization. Journal of Consumer Health on the Internet, 15(1), 69-74. http://dx.doi.org/10.1080/15398285.2011.547091

Ball, M.A. (2008). Practicums and service learning in LIS education. Journal of Education for Library and Information Science, 49(1), 70-82.

Bird, N. \& Crumpton, M.A. (2014). Real Learning Connections: Questioning the learner in the LIS internship. Journal of Education for Library and Information Science (JELIS), 55(2), 89-99.

Cargo, R. (2000). Made for each other: Nonprofit management education, online technology, and libraries. Journal of Academic Librarianship, 26(1), 15-20.

Coleman, J.G., Jr. (1989). The role of the practicum in library schools. Journal of Education for Library and Information Science, 30(1), 19-27.

Salinas, R. \& Chabrán, R. (2005/2006). Preparing ethnic non-profits for the 21st century. In W. Miller \& R.M. Pellen (Eds.), Libraries Beyond Their Institutions: Partnerships That Work (pp. 121-136). Binghamton, NY: Haworth Press. doi: 10.1300/J121v18n01_10

The University of North Carolina at Greensboro School of Education. (2013). Library and Information Studies (LIS). Retrieved from http://soe.uncg.edu/academics/departments/lis/

The University of North Carolina at Greensboro Walter Clinton Jackson Library. (2015). Mission statement, goals \& customer service values. Retrieved from https://library.uncg.edu/info/mission_statement.aspx 